\title{
Uspješnije usvajanje bioloških sadržaja uz objašnjenja naziva biljaka
}

\author{
Jelena Barbarić - Gaćina \\ Prirodoslovno-grafička škola Zadar, Perivoj Vladimira Nazora 3, 23000 Zadar, Hrvatska \\ jelena.gacina@zd.t-com.hr
}

\begin{abstract}
SAŽETAK
Povezivanje gradiva dva ili više nastavnih predmeta doprinosi poticanju učenika na uočavanje veza između obrađivanih sadržaja i mogućnosti primjene usvojenih sadržaja u svakodnevnom životu. U ovom radu učinjeni su koraci prema mogućem povezivanju biologije s klasičnim jezicima prilikom obrade nastavne teme Biološka raznolikost u pozitivnom i motivirajućem okruženju uz razvoj vještina korištenja stručne literature, rada na tekstu, izrade plakata, prezentiranja i suradnje s drugim učenicima. Provjera provedena nakon obrade nastavnih sadržaja pokazala je da se učenici eksperimentalne skupine bolje snalaze u primjeni znanja od kontrolne skupine, ali za značajnije rezultate potrebno je više nastavnih sadržaja obrađivati na ovaj način. Primjena ovakve nastave obećavajući je smjer kojim bi se mogli postići bolji rezultati usvajanja znanja za cjeloživotno učenje, kritičko razmišljanje i veću samostalnost pri učenju.
\end{abstract}

Ključne riječi: biologija; klasični jezici; nazivi biljaka; rad na tekstu; izrada plakata

\section{UVOD}

Tradicionalno obrazovanje temelji se na usvajanju činjeničnog znanja, dok je suvremeno obrazovanje okrenuto usvajanju vještina, vrijednosti i stavova te znanja koje će učenik primijeniti u rješavanju problema uz razvoj kritičkog mišljenja i kreativnosti (Vrančić i sur., 2011). Učenici trebaju aktivno sudjelovati u nastavi čime se potiče samostalnost učenika i njihovo kritičko razmišljanje, a na taj način učenici preuzimaju odgovornost za vlastito učenje, razvijaju socijalne vještine i kvalitetnije usvajanje znanja (Tomljenović i Novaković, 2012). Jedno od mogućih rješenja uvođenje je interdisciplinarne nastave koja povezuje gradivo dva ili više nastavnih predmeta, a može se provoditi kao integracija dva (ili više) predmeta na jednom i/ili više sati pri obradi neke nastavne jedinice i/ili teme ili kao integrirani dan (Salopek, 2012). Korelacijska, projektna, timska nastava pojmovi su koji se spominju u raspravama o suvremenoj nastavi, ali praktično još nisu zaživjeli (Martinić - Jerčić i Tvrtković, 2016), a što se vidi po malom broju dostupnih primjera. Nastava biologije može se povezati s velikim brojem predmeta. Ništ (2014) navodi primjere povezivanja biologije s tjelesnom i zdravstvenom kulturom, hrvatskim jezikom, kemijom i matematikom, ali bez detaljnijeg objašnjenja prednosti i učinkovitosti ovakvog pristupa obradi nastavnih sadržaja. Opisana je i mogućnost integracije biologije s grafičkom grupom predmeta (Barbarić - Gaćina i Perić, 2017), dok Dolenec i Dolenec (2013) predlažu međupredmetnu korelaciju biologije i geografije pri obradi nastavne jedinice Ptice.

U posljednjem desetljeću interes mladih ljudi za prirodne znanosti opada i premda su učenici svjesni važnosti biologije, ne uočavaju njezinu vezu sa svakodnevnim životom (Vacha i Rokos, 2017). Slično je i s učenjem latinskog ili grčkog jezika kao klasičnih jezika koje uče učenici u gimnazijama, a doživljavaju in kao nešto dosadno, zastarjelo, bespotrebno i ne povezivo s bilo čim suvremenim (Martinić - Jerčić i Tvrtković, 2016), premda i riječ kompjuter (engl. computer) dolazi od latinske riječi computo što znači zbrajati, brojati. Do kraja sedamnaestog stoljeća znanstvene knjige pisane su latinskim jezikom, pa se on i danas koristi u botanici, zoologiji, medicini, farmaciji, veterini, šumarstvu i pravu, te ga možemo nazvati i jezikom znanosti (ili znanja) (Rizal i sur., 2013). Mnoge latinske riječi (e sfera, 2020) koristimo i u svakodnevnom životu - reuma lat. rheuma, ae, f. (kostobolja), lat. luxus - raskoš, kićenost (luksuz, raskoš).

Barbarić - Gaćina, J. (2019). Uspješnije usvajanje bioloških sadržaja uz objašnjenja naziva biljaka. Educ. biol., 5:78-86. URL DOI: https://doi.org/10.32633/eb.5.6 
Cilj nastave u ovom radu bio je istražiti postojanje mogućnosti kvalitetnog ostvarivanja učenja povezivanjem naziva biljaka s poznavanjem značenja tih naziva na klasičnim jezicima. Nastava je provedena u okružju za koje se pretpostavlja da će učenike motivirati na aktivno učenje uz razvijanje vještina i znanja kroz pozitivan odnos prema usvajanju istih. Nakon obrade nastavnih sadržaja provedena je pisana provjera kako bi se utvrdilo mogu li učenici primijeniti znanje kroz rješavanje novih primjera zadataka. Osim toga, željelo se provjeriti kakvi su učenički dojmovi kad se nastavni sadržaji obrađuju uz aktivno sudjelovanje učenika kroz grupni rad na tekstu i izradu plakata. Postavljeni su sljedeći specifični ciljevi nastave: opisati binarni sustav imenovanja organizama, objasniti zašto se za imenovanje organizama koristi latinski jezik, upoznati naslijeđe Rimljana koje nalazimo u današnjem vremenu, razvoj suradnje i prezentacijske kompetencije kod učenika, korištenje literature i drugih relevantnih izvora informacija (Internet) te uočavanje utjecaja Rimljana na današnje civilizacije.

\section{METODE}

U istraživanju su sudjelovali učenici prvog razreda strukovnih škola (smjer: Kemijski tehničar i Upravni referent). Oni latinski jezik uče kao izborni ili fakultativni jezik i bili su eksperimentalna skupina, a u sklopu nastave biologije obrađuju nastavnu temu Biološka raznolikost. Učenici drugih razreda, isti smjerovi, su kontrolna skupina, jer su obradili nastavnu temu Biološka raznolikost na klasičan način. Prilikom obrade sadržaja s kontrolnom skupinom korišteni su primjeri biljaka kao kod kontrolne skupine, ali bez objašnjenja značenja imena, istraživanja porijekla imena i izrade plakata. Ukupno je anketirano 57 učenika.

Nastava se izvodila kroz dva školska sata na nastavi biologije. Na početku sata učenici su raspravljali o biološkoj raznolikosti, brojnosti organizama na Zemlji te mogućnosti snalaženja u tolikoj brojnosti organizama. Nastavnik je objasnio dvoimeno nazivlje nakon čega su učenici raspravljali o važnosti klasičnih jezika u imenovanju organizama. Učenici su pomoću tablice s latinskim i grčkim riječima te značenjem na hrvatskom jeziku rješavali radni listić na kojem su otisnute slike biljaka s latinskim nazivima ispod biljke, a na dnu stranice nalazili su se hrvatski nazivi biljaka. Koristeći dobivenu tablicu učenici su trebali odrediti koji hrvatski naziv odgovara kojoj biljci (npr. Quercus rubra = crveni hrast; Betula albe = bijela breza). Za izradu tablice i nastavnih listića korišteni su sljedeći izvori: "What's so important about names?" (2019), "Lesson 5. What's in a Name?” (2019), "Lesson 2: Plant classification” (2019) i Domac, 1984.

Na drugom nastavnom satu učenici su uz prethodni dogovor donijeli materijale za izradu plakata o biljkama. Učenici su također upućeni da fotografiraju biljku koju će obrađivati u svom okolišu i donesu fotografiju, ako je pronađu. Obrađene su biljke: tetivika, bršljan, čempres, bugenvilija, lovor. Učenici su podijeljeni u pet grupa po četiri učenika i svaka grupa obrađivala je jednu biljku. Učenici su koristili sljedeću literaturu: Černicki, 2006; Domac, 1984; Kovačić i sur., 2008; Lanzara i sur., 1982; Nikolić i sur, 2008 i Škrtić, 2012. U oba eksperimentalna razreda obrađene su iste biljke te izrađeni plakati. Svaka grupa je prezentirala svoj rad, nakon čega su riješili pisanu provjeru te anketu kojom je provjerena razina zadovoljstva integriranom nastavom. Pisanu provjeru i anketu riješili su i učenici kontrolne skupine.

\section{REZULTATI}

Biljke koje su učenici obrađivali uz sebe vežu određene priče i legende ili se u njihovom nazivu krije osobina biljke (npr. Smilax aspera; lat. aspera=gruba, bodljikava) po kojoj je biljka imenovana. $U$ tablici 1 , koja je prikazana u skraćenom obliku za potrebe ovog članka, navedena su značenja naziva biljaka 
te legende vezane uz biljku ili njezinu osobinu. Za pronalaženje informacija učenici su koristili dostupnu literaturu: Gligić, 1954; Černicki, 2006; Kovačić i sur., 2008; Škrtić, 2012.

Tablica 1 Biljke obrađene i prezentirane pomoću plakata

\begin{tabular}{|c|c|c|}
\hline $\begin{array}{l}\text { NAZIV } \\
\text { BILJKE }\end{array}$ & ZNAČENJE NAZIVA (RJEČNIK) & LEGENDA ili OSOBINA \\
\hline$B R S ̌ L J A N$ & $\begin{array}{l}\text { nazivi: barsijan, beštran, bršljen, brštan } \\
\text { hedera, ae f. bršljan (Bakhov štap bijaše njime } \\
\text { ovijen) } \\
\text { helix, icis f. nekakva lozasta biljka } \\
\text { grč. hedra - sjedište; bršljan je čvrsto pripijen za } \\
\text { podlogu. } \\
\text { U prošlosti bila je simbol besmrtnosti, životne } \\
\text { snage i radosti kod starih Grka, a pjesnicima } \\
\text { simbolom vječne ljubavi i odanosti (ukrašavali } \\
\text { glave). }\end{array}$ & $\begin{array}{l}\text { U grčkoj i rimskoj mitologiji bršljan se veže uz boga vina Dioniza i } \\
\text { Bakha. Legenda kaže da se božica zemlje Gea smilovala nad } \\
\text { umirućim Dionizijevim sinom Kissosom (grč. Kissos = bršljan) i } \\
\text { pretvorila ga u bršljan. Vjerujući u legende o besmrtnosti Rimljani } \\
\text { su pokojnike polagali na daske obavijene bršljanom. Bršljan je i } \\
\text { motiv mnogih slika srednjovjekovnih crkava. }\end{array}$ \\
\hline BUGENVILIJA & lat. spectabilis - sjajan, ugledan & $\begin{array}{l}\text { Rod Bougainvillea dobio je naziv po francuskom pomorcu, } \\
\text { admiralu de Bougainvilleu koji je sredinom 18. stoljeća oplovio } \\
\text { svijet i prenio bogumile iz Brazila. Ljudi vjeruju da zbog kićenih } \\
\text { boja donose nesreću prizivajući nevrijeme na moru. }\end{array}$ \\
\hline ČEMPRES & $\begin{array}{l}\text { Cupressus - grč. kyeo=proizvodim, } \\
\text { parisos=jednake grane - zbog jednakog pravca } \\
\text { grana. } \\
\text { sempervirens - uvijek zelen }\end{array}$ & $\begin{array}{l}\text { U dvorištu franjevačkog samostana u Hvaru nalazi se čempres star } \\
\text { oko } 500 \text { godina koji je zaštićeni spomenik prirode od } 1961 . \\
\text { godine. Najpoznatiji predmet izrađen od čempresovine vrata su } \\
\text { bazilike Sv. Petra u Rimu koja su trajala oko } 800 \text { godina. Latinski } \\
\text { naziv rod duguje mladiću Kyparissosu kojeg je bog Apolon, na } \\
\text { njegov zahtjev, pretvorio u drvo čempresa - simbol tuge, nakon } \\
\text { što je slučajno kopljem ubio jelena o kojem se brinuo. }\end{array}$ \\
\hline LOVOR & $\begin{array}{l}\text { nazivi: lovorika, lovor, lavorika, lorber, lavrika, } \\
\text { javorika } \\
\text { laurus - ime za lovor kod Rimljana; potječe od } \\
\text { keltskog „blaur“- uvijek zelen }\end{array}$ & $\begin{array}{l}\text { Stablo lovora bilo je posvećeno bogu Apolonu. Kult je prenesen u } \\
\text { Rim pa su se lovorovim lišćem krunile glave pjesnika i pobjednika } \\
\text { (riječ laureat potječe od imena roda, a akademska titula mag. } \\
\text { baccalaureate od naziva lovorove bobe lat. bacca=boba). }\end{array}$ \\
\hline
\end{tabular}

TETIVIKA Smilax - grč. smile $=$ češagija - čelična naprava za češljanje konja; antičko ime za sasvim različite biljke; lat. asper - grub, bodljikav

Smrtnik Crocus i šumska nimfa Smilax (grčka mitologija) su se zaljubili, ali je ljubav završila tragično. Mladić je pretvoren u šafran (Crocus), a nimfa u tetiviku.

\section{Izrada plakata}

Nakon obrade nastavnih sadržaja vezanih uz raznolikost živog svijeta i dvoimeno nazivlje te rješavanja radnih listića, učenici su na drugom nastavnom satu izradili plakate o biljkama: tetivici, bršljanu, čempresu, bugenviliji i lovoru, radeći u grupama. Nakon izrade plakata, svaka grupa učenika prezentirala je svoj plakat i upoznala ostale učenike u razredu o osobinama biljke koju su obradili, povezanosti neke osobine biljke s njezinim imenom te legendom koja se veže uz tu biljku.

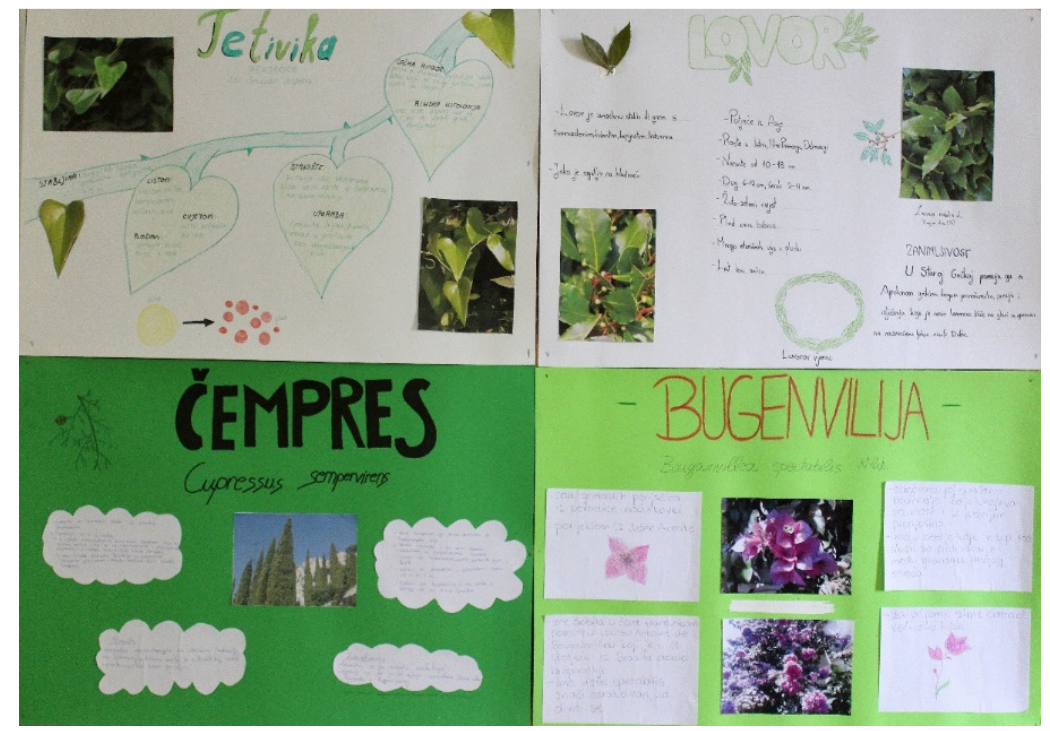

Slika 1 Plakati izrađeni tijekom obrade nastavnih sadržaja 


\section{Rješenja radnog listića za provjeru znanja}

$\mathrm{Na}$ kraju drugog sata učenici su rješavali listić s pitanjima u svrhu vrednovanja usvojenosti i razumijevanja obrađenih nastavnih sadržaja uz mogućnost primjene znanja na nove primjere.

Prvi je zadatak bio povezati latinske nazive biljaka s hrvatskim nazivima koristeći znanje klasičnih jezika, npr. Hyoscyamus albus (alba=bijela) je bijela bunika. Postotak točnog označavanja biljaka Portulaca grandiflora i Reichardia macrophylla kod eksperimentalne skupine je $97 \%$, postotak točnog označavanja Arum nigrum je 87 \%, a Hyoscyamus albus 82 \% (Slika 2). U kontrolnoj skupini najbolje je riješen zadatak 1d) gdje je trebalo označiti Reichardia macrophylla $55 \%$, zatim zadatak 1c) gdje je trebalo označiti Portulaca grandiflora 50\%; Hyoscyamus albus je riješen s 32 \% točnošću, a Arum nigrum $27 \%$ (slika 2).

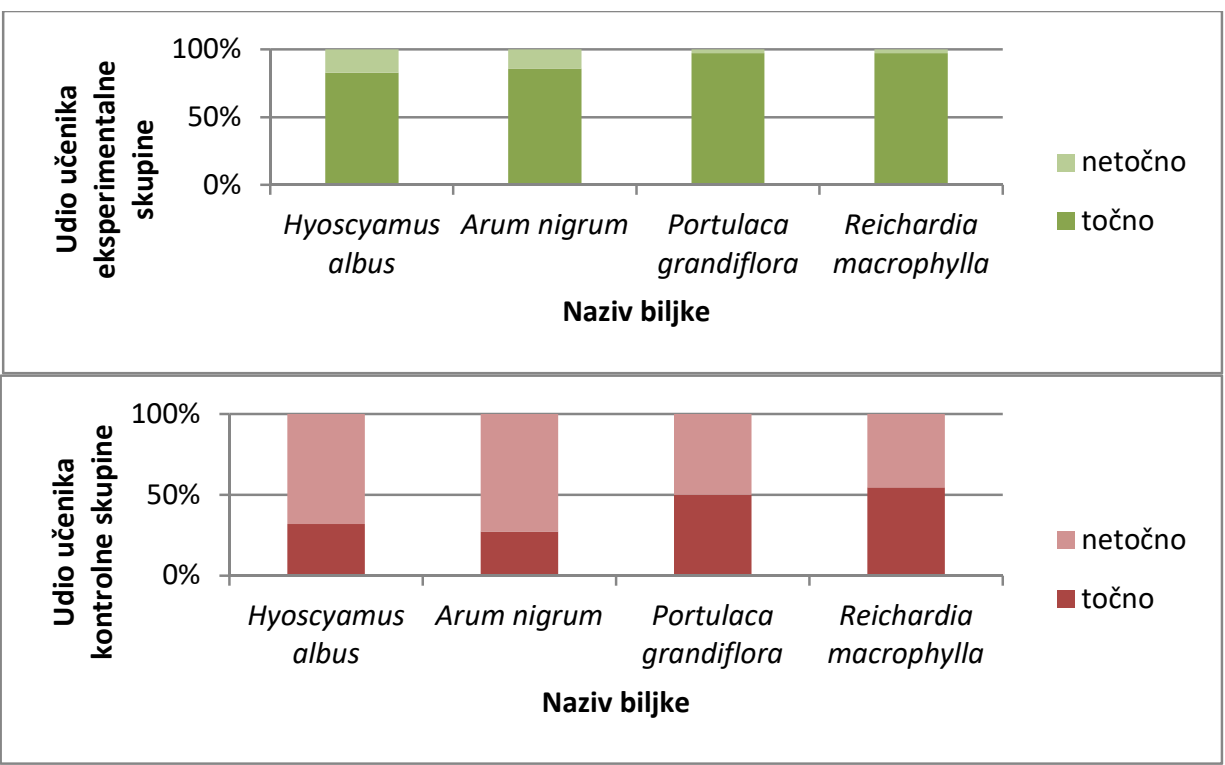

Slika 2 Rješenja uz zadatak povezivanja latinskih naziva biljaka s hrvatskim nazivima

$\mathrm{U}$ drugom zadatku trebalo je na prazne crte upisati ime biljke pored principa koji odgovara njezinom imenovanju. U zadatku su navedena četiri pravila: imenovanje $u$ čast osobe, opisuje dio biljke, opisuje boju nekog dijela biljke ili ukazuje na područje iz kojeg biljka potječe. Eksperimentalna skupina najbolje je povezala ime koje opisuje boju nekog dijela biljke s biljkom - Bryonia alba, s točnošću od $91 \%$. Postotak riješenosti 2. zadatka u kontrolnoj skupini (slika 3) je sljedeći: Campanula tommasiniana $0 \%$, Centaurea ragusina i Aristolochia rotunda 9 \% te Bryonia alba $18 \%$.

U trećem zadatku trebalo je povezati latinski s hrvatskim nazivom biljaka, od kojih je pet biljaka obrađivano na nastavi, a šesta biljka je biljka koja se spominje kroz obrazovanje (petrovac). Osim toga u zadatku su fotografije svih šest biljaka koje onda treba pravilno označiti. Eksperimentalna skupina (Slika 4) je u 3. zadatku kod povezivanja latinskih i hrvatskih naziva biljke obrađene na satu povezala s preko $90 \%$ točnošću osim bršljana ( $85 \%$ točnost). Eksperimentalna skupina je i petrovac uglavnom točno riješila (94 \%). Kod kontrolne skupine (slika 4) najbolje je riješena bugenvilija (50 \%), a najlošije bršljan (32 \%). 


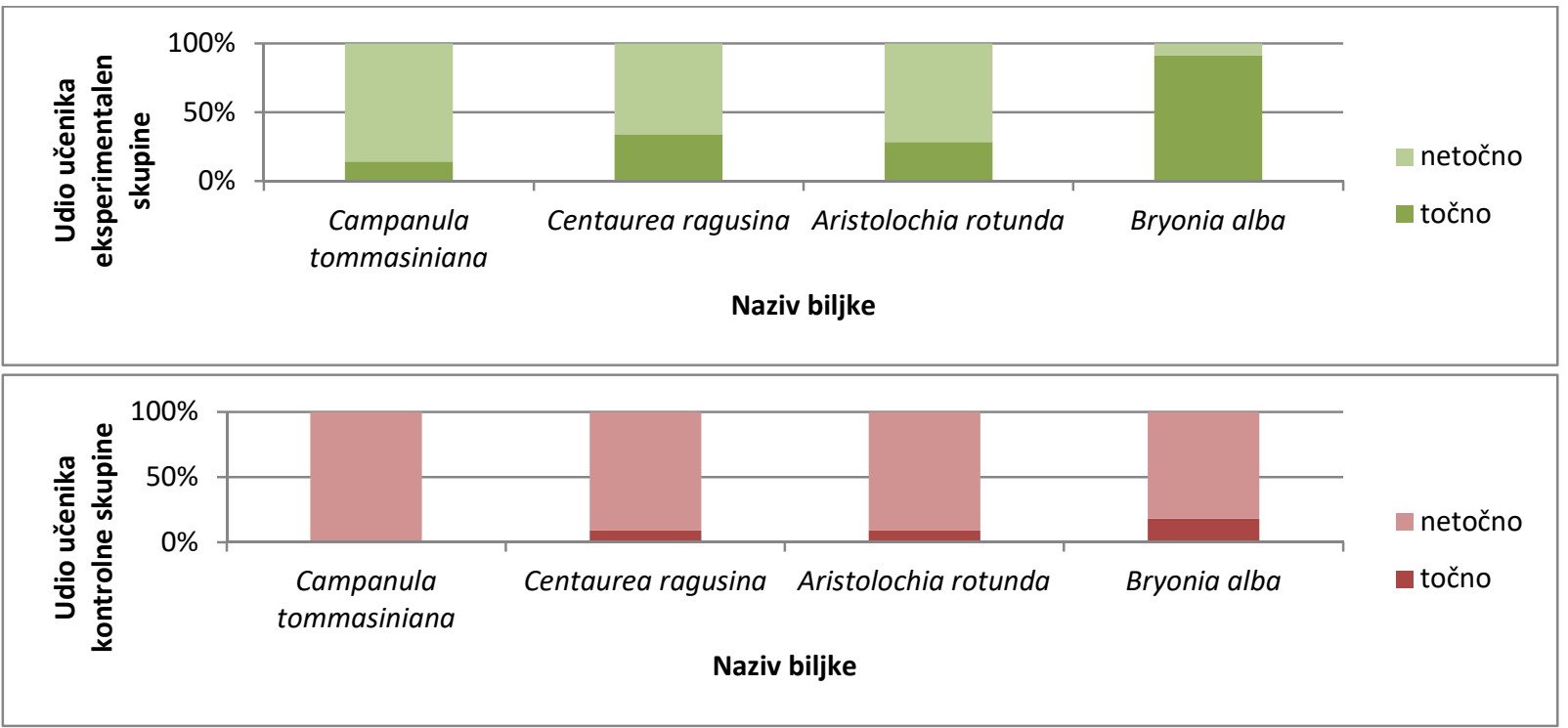

Slika 3 Rješenja uz zadatak uočavanja principa koji odgovara njezinom imenovanju

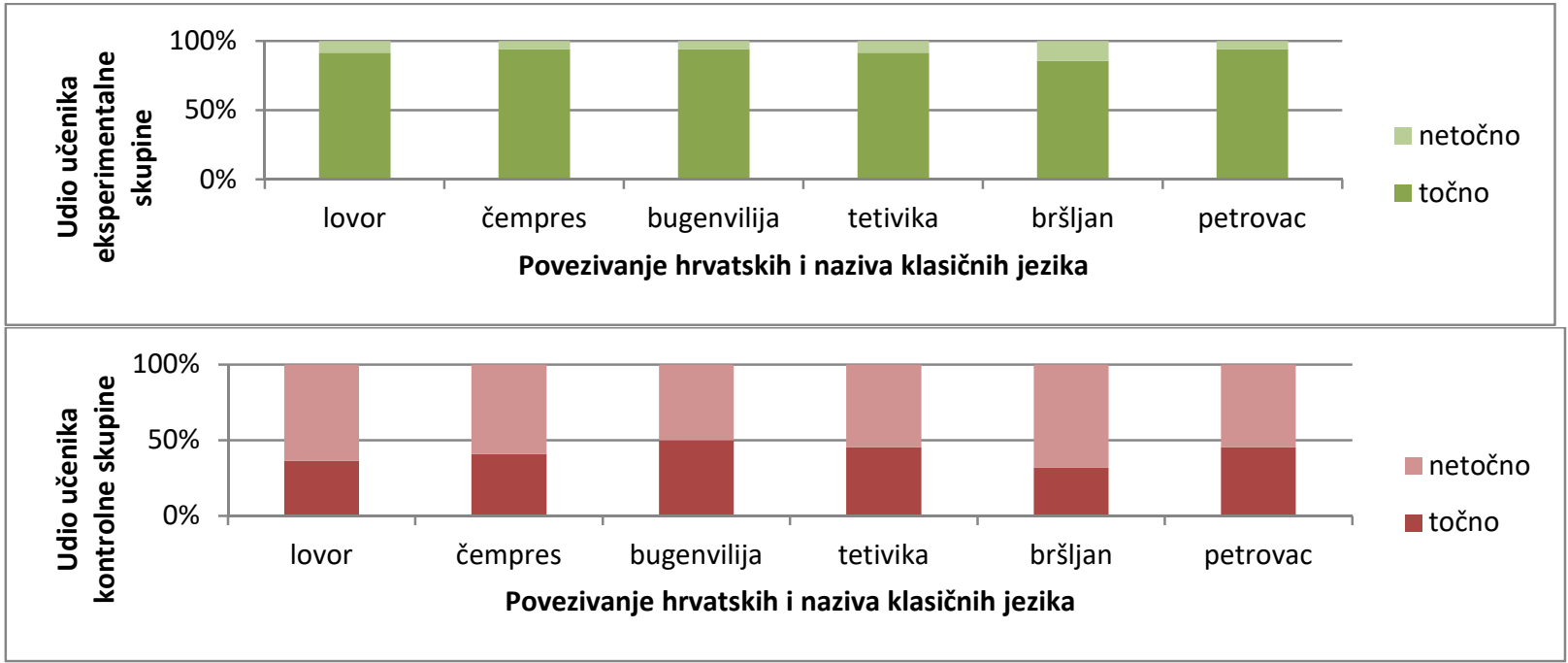

Slika 4 Rješenja povezivanja latinskih i hrvatskih naziva

Eksperimentalna skupina (slika 5) je u 3. zadatku kod prepoznavanja biljaka pomoću slika sa $100 \%$ točnošću prepoznala bugenviliju, lovor i čempres. Kod kontrolne skupine (Slika 5) učenici su najbolje prepoznali bršljan i čempres ( 82 \% točnost), a najlošije petrovac (50 \%).

$\mathrm{U}$ istraživanju je ispitano i zadovoljstvo učenika obradom gradiva radom u parovima i grupama. $\mathrm{Na}$ pitanje Sviđa mi se obrada gradiva putem izrade plakata i radom u grupi jer je zanimljivije i kreativnije $60 \%$ učenika eksperimentalne skupine zaokružilo je procjenu 5 (na mogućoj skali od 1 - jako mi se ne sviđa do 5 - jako mi se sviđa), dok je 50 \% učenika kontrolne skupine na isto pitanje zaokružilo broj 1 (slika 6). 


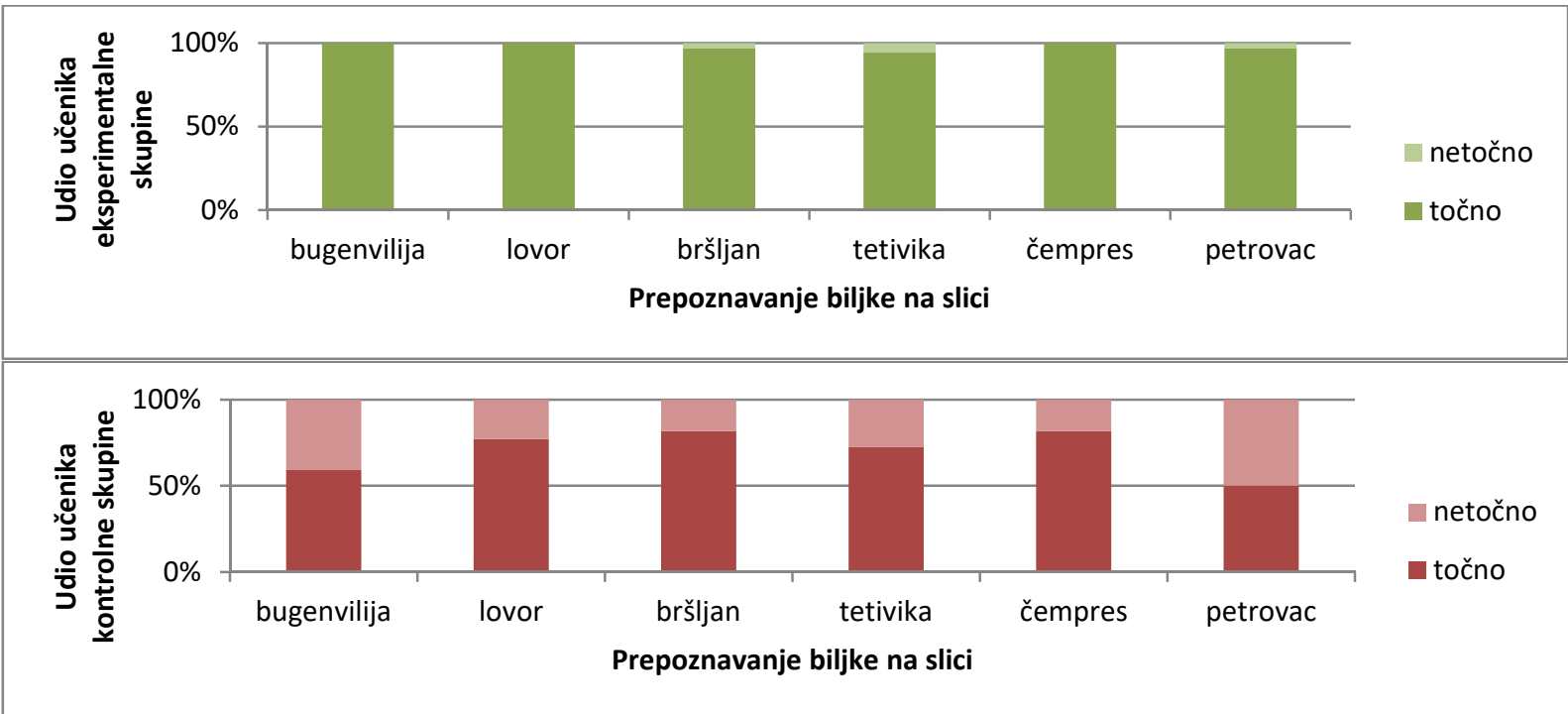

Slika 5 Rješenja prepoznavanja biljaka na slikama

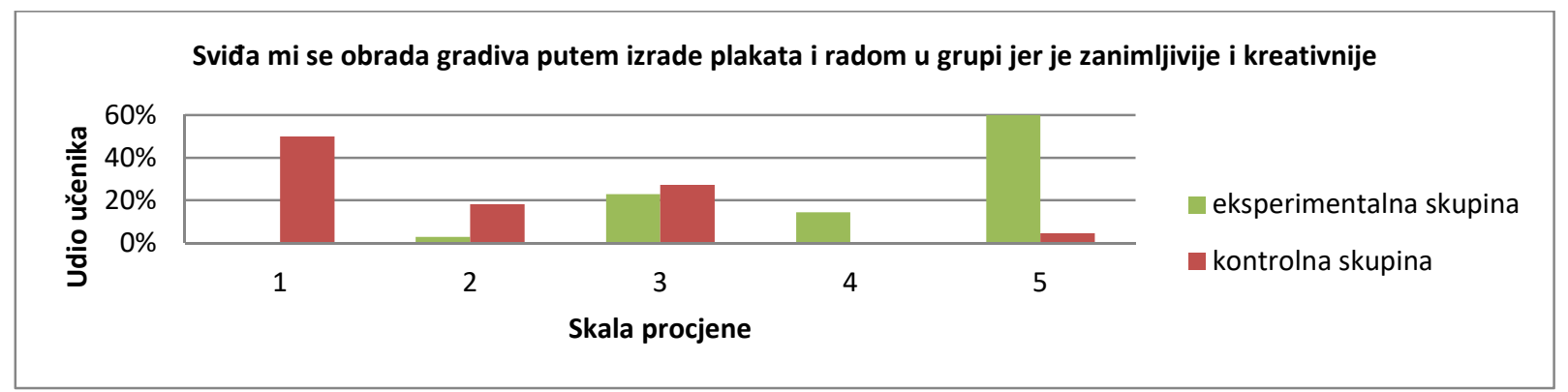

Slika 6 Iskaz zadovoljstva učenika uz obradu gradiva kroz izradu plakata

Na pitanje Više volim klasičnu nastavu jer se tada ne moram previše truditi na satu u eksperimentalnoj skupini najviše učenika, 25 \% zaokružilo je broj 5 , dok su ostale vrijednosti odabrane u rasponu od 14 - 22 \% (Slika 7). U kontrolnoj skupini učenici su uglavnom odabrali 3, 4 i 5 (slika 7).

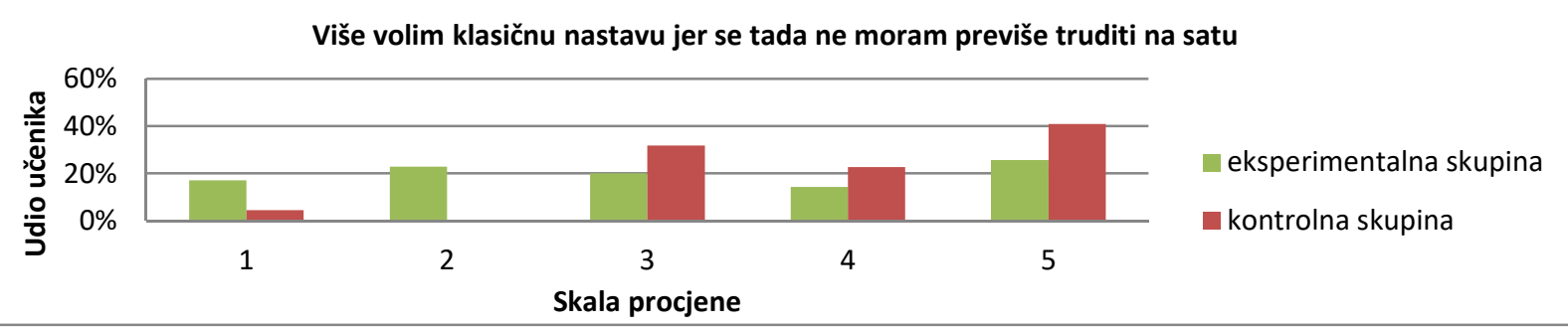

Slika 7 Zadovoljstvo učenika eksperimentalne i kontrolne skupine obradom gradiva klasičnim putem

Rezultati odgovora na pitanje Nastava na kojoj sami radimo mi je puno zanimljivija pokazuje da $50 \%$ učenika kontrolne skupine ne smatra da samostalni rad na satu znači zabavniju nastavu (slika 8).

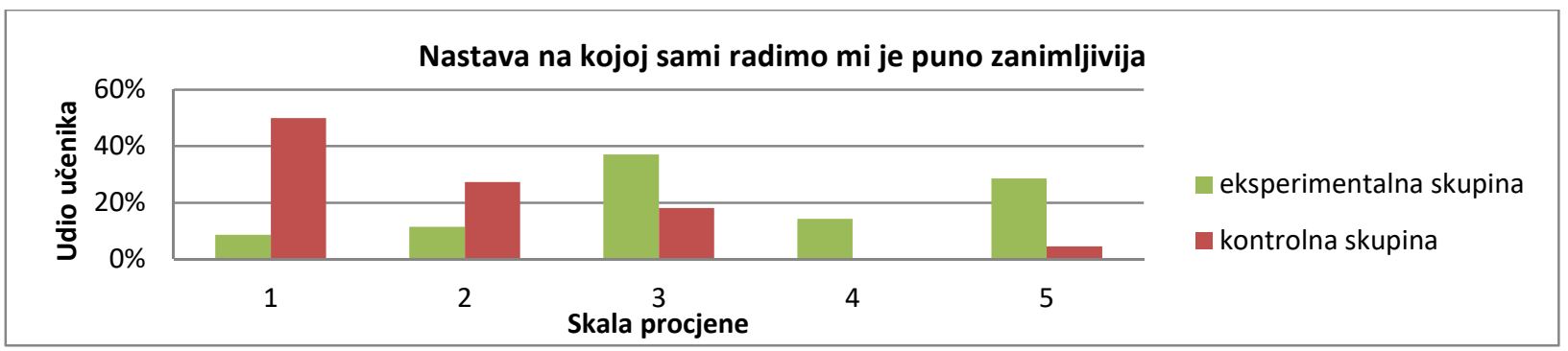

Slika 8 Zadovoljstvo učenika radom na tekstu i uz izradu plakata 


\section{RASPRAVA}

Znanstvenici diljem svijeta raspoznaju biljke i životinje koristeći klasične jezike, a učeći klasične jezike ili barem samo latinski jezik možemo na temelju imena biljke ili životinje zaključiti i ponešto o njoj, npr. boju, oblik, prilagodbu, odakle potječe. Upravo stoga biologija i klasični jezici čvrsto su povezani. Nakon obrade nastavne teme Biološka raznolikost uočene su mnoge poveznice i s drugim predmetima kao što su povijest (legende i vjerovanja), glazbeni (legenda o bršljanu u priči o Lesolt i Tristanu koju je obradio Wagner u operi Tristan i Izolda), geografija (bugenvilija - naziv je dobila po francuskom pomorcu koji je bugenviliju pronašao u Brazilu i prenosio je dalje na svom putu oko svijeta u 18. stoljeću), hrvatski jezik (prefiksi i sufiksi) i grčki jezik. Martinić - Jerčić i Tvrtković (2016) predlažu integraciju latinskog jezika s hrvatskim i grčkim jezikom, poviješću, geografijom, etikom, likovnom i glazbenom umjetnošću, što odgovara uočenim mogućnostima povezivanja pri obradi ove nastavne teme. Uz likovnu umjetnost koja bi se mogla integrirati izradom obrađenih biljaka različitim likovnim tehnikama, postoji mogućnost povezivanja i kemije (Cil, 2015). Prema tome, latinski jezik osim s humanističkim i društvenim znanostima može se povezati i s prirodnim znanostima.

Obrada nastavnih sadržaja grupnim radom uz veću uključenost učenika pokazala je veće zadovoljstvo učenika s takvim oblikom rada, premda ne i oduševljenje. Razlog tome može biti što dio učenika i dalje preferira pasivnost na satu gdje se od njih ne očekuje aktivno sudjelovanje, što grupni rad podrazumijeva (Ruić, 2007). Aktivnim učenjem i uključivanjem učenika u rad na satu kroz rad u grupi potiču se procesi učenja i razumijevanja gradiva kako bi učenici razvijali kritičko razmišljanje i primjenjivali znanje (Ruić, 2007), uz razvoj socijalnih i prezentacijskih vještina.

Jedan od ciljeva rada bio je utvrditi mogu li učenici nakon obrade gradiva povezivanjem nastavih sadržaje, obrađene sadržaje primijeniti na nove primjere kroz rješavanje zadataka u testu gdje je eksperimentalna skupina imala bolje rezultate. Kod određivanja biljaka koje su imenovane u čast neke osobe ili opisa dijela biljke $u$ istom zadatku, slabiji postotci riješenosti posljedica su nezgodnog izbora biljke Aristolochia rotunda koja je primjer za imenovanje prema opisu dijela biljke (rotundus adi. obal, okrugao), ali je učenike prema njihovim izjavama asocirala na Aristotela pa su je mnogi naveli kao biljku imenovanu u čast neke osobe. $U$ zadatku gdje su učenici trebali povezati latinske i hrvatske nazive biljaka i eksperimentalna i kontrolna skupina najlošije su riješile bršljan, što je iznenađujuće jer se naziv za tu biljku pojavljuje i u svakodnevnom životu, npr. sirup za kašalj od bršljana - Hederan. U kontrolnoj skupini najbolje je riješena bugenvilija, vjerojatno stoga što je naziv za bugenviliju sličan i latinskom Bougainvillea. Premda eksperimentalna skupina ima bolje rezultate, što je i očekivano, za razvoj kritičkog razmišljanja i primjenu znanja uz povezivanje već postojećih znanja potrebno je puno više aktivnog učenja i integracije nastave kako bi se učenici osposobili za kreativnije razmišljanje $i$ cjeloživotno učenje.

\section{ZAKLUČAK I METODIČKI ZNAČAJ}

Aktivnim učenjem kod učenika se potiče kritičko razmišljanje, ali učenici naviknuti na pasivno učenje teško mijenjaju svoje navike. Eksperimentalna skupina imala je bolje rezultate nakon provedenog testiranja koje je slijedilo nakon obrade nastavnih sadržaja, ali za značajnije razlike trebalo bi više nastavnih sadržaja obraditi povezivanjem sadržaja dvaju predmeta.

Učenici obrađuju novo gradivo aktivnim učenjem kombinirajući znanja iz više predmeta. Korištenjem različitih informacija iz više izvora znanja učenici vježbaju uočavanje činjenica bitnih za njihovo istraživanje. Korištenjem Interneta učenici uvježbavaju traženje informacija u digitalnom okruženju i 
procjenjuju pouzdanost izvora informacija. Izradom plakata razvijaju mogućnost rada u timu odnosno grupi i poboljšavaju sposobnost prezentacije.

\section{LITERATURA}

Cil E (2015). Integrating Botany with Chemistry and Art to Improve Elementary School Children`s Awareness of Plants. The American Biology Teacher, Vol. 77:348-355.

Černicki L (2006). Samoniklo cvijeće grada Zagreba, Školska knjiga, Zagreb

Dolenec Z, Dolenec P (2013). Correlation in Teaching Biology and Geography. Croatian Journal of Education, Vol.15. Sp. Ed. No2:267-274.

e sfera (2019.: Lectio secunda: Podrijetlo i uloga latinskoga jezika, Školska knjiga d.d., https://www.e-sfera.hr/dodatni-digitalnisadrzaji/b6a4d327-a63b-45fb-9718-331ca744b704/, preuzeto 28.5.2019.

Domac R (1984). Mala flora Hrvatske i susjednih područja, Školska knjiga, Zagreb

Gligić V (1954). Etimološki botanički rečnik, Veselin Masleša, Sarajevo

Kovačić S, Nikolić T, Ruščić M, Milović M, Stamenković V, Mihelj D, Jasprica N, Bogdanović S, Topić J (2008). Flora jadranske obale i otoka - 250 najčešćih vrsta, Školska knjiga, Zagreb

McHenry, E.J. (2019). Lesson 2: Plant classification, Basement workshop. http://www.ellenjmchenry.com/homeschoolfreedownloads/lifesciences-games/documents/BotanySecondChapter 000.pdf, preuzeto 8.10.2018.

McHenry, E.J. (2019). Lesson 5. What's in a Name?, Basement workshop. https://www.marine.usf.edu/pjocean/packets/f99/f99u2le5.pdf, preuzeto 8.10.2018.

Martinić - Jarčić Z, Tvrtković T (2016). Prodesse et delectare u nastavi latinskog jezika i književnosti - novi pristup na starim temeljima, Kroatologija 7, 1:75-90

Nikolić T, Kovačić S (2008). Flora Medvednice, Školska knjiga, Zagreb

Ništ M (2014). Primjer unaprjeđivanja nastave biologije i nastave ostalih predmeta suradnjom učitelja različitih struka. Educ.biol. 1:97-99.

Rizal A, Er AC, Ramli ZB, Jali MFM (2013). Occidentalism and Latin language: The Linqua Franca of Knowlege, Asian Social Science Vol 5, No. 14

Ruić R (2007). Stavovi gimnazijskih učenika prema grupnom radu u nastavi kemije. Život i škola br.17

Salopek A (2012). Korelacija i integracija u razrednoj nastavi, Školska knjiga, Zagreb

Tomljenović Z, Novaković S (2012). Integrirana nastava - projekt u izbornoj nastavi likovne kulture u osnovnoj školi. Metodički obzori 7/1

Škrtić D (2012). Biljke kroz mitove i legende - drugi dio (http://biologija.com.hr/modules/AMS/article.php?storyid=8601) (posljednji put posjećeno 12.12. 2019)

Vrančić M, Lovrenčić S, Novosel D (2011). Senzibilizacija učenika i učitelja za uvođenje obrazovanja za poduzetništvo u osnovne škole, Učenje za poduzetništvo, Vol.1., No 1., str. 289 - 293.

LSL (2019). What's so important about names? Educational resources from the Linnean Society of London. https://ca1tls.edcdn.com/documents/Worksheet-2a.pdf?mtime=20160830154347, preuzeto 8.10.2018. 


\title{
Improved learning of biological concepts through the explanation of plant
}

\section{names}

\author{
Jelena Barbarić - Gaćina \\ Natural History and Graphic School Zadar, Vladimir Nazora 3 Park, 23000 Zadar, Croatia \\ jelena.gacina@zd.t-com.hr
}

\begin{abstract}
Connecting curriculum two or more subjects, encourages students to recognize the links among different subjects and the possibility of implementing their knowledge in everyday life. In this paper Biology and Classical languages have been integrated during the tuition of the lesson Biological Differences with the purpose of learning and connecting some elements of Classical languages and Biology in positive and motivating surrounding and at the same time developing the skill of using the necessary literature, presentation and interaction with other students. Testing made after such tuition, showed that students from the experimental group possess better ability to implement their knowledge from the control group, but for the more significant results it is necessary to include more units presented and taught this way. The implementation of such teaching methods is a promising approach that might achieve better results in life learning, developing critical thinking and resulting in more independent learning.
\end{abstract}

Keywords: biology; classical languages; names of plants; text learning; making of posters 